\title{
Intraspinal Injection of Platelet-Rich Plasma Promotes Regeneration of the Spinal Cord and Improves Locomotor Function by Modulating the Apoptosis and the Wnt Signaling Pathways
}

\author{
Zahra Behroozi \\ Iran University of Medical Sciences \\ Fatemeh Ramezani \\ Iran University of Medical Sciences \\ farinaz Nasirinezhad ( $\sim$ nasirinezhadfarinaz@yahoo.com ) \\ Iran University of Medical Sciences
}

\section{Research}

Keywords: Spinal cord injury, regeneration, Platelet rich plasma, apoptosis, Wnt signaling

Posted Date: March 30th, 2021

DOl: https://doi.org/10.21203/rs.3.rs-365438/v1

License: (c) (1) This work is licensed under a Creative Commons Attribution 4.0 International License. Read Full License 


\section{Abstract}

Background: There are complex mechanisms for reducing intrinsic repair ability and neuronal regeneration following spinal cord injury $(\mathrm{SCl})$. Platelet-rich plasma (PRP) is a rich source of growth factors and has been used to stimulate regeneration of peripheral nerves in degenerationtive diseases. However, only a few studies have investigated the effects of PRP on the SCl models. We examined whether PRP derived from human umbilical cord blood (HUCB-PRP) could recover motor function in animals with spinal cord injury. We also investigate the role of Wnt signaling pathway.

Methods: Ault male Wistar rats were randomly divided into 6 groups $(n=60)$ as control, sham, SCl, vehicle (SCl+platelet-poor plasma), PRP2day (SCl+injection 2 days after SCl) and PRP14day (SCl+injection 14 days after $\mathrm{SCl}$ ). $\mathrm{SCl}$ was performed at the T12-T13 level. BBB tests were done weekly after injury for six weeks. caspase 3 expression was determined using the Immunohistochemistry technique. The expression of GSK3 $\beta$, Tau and MAG were determined using the Western blot technique. Data were analyzed by PRISM \& SPSS software.

Results: PRP injected animals showed a higher locomotor function recovery than those in the $\mathrm{SCl}$ group $(p<0.0001)$. The level of caspase3, GSK3 $\beta$ and CSF- Tau reduced and MAG level in the spinal cord increased by injection of HUCB-PRP in animals with spinal cord injury.

Conclusions: Injection of HUCB-PRP enhanced hind limb locomotor performance by modulation of caspase3, GSK3 $\beta$, tau and MAG expression. Using HUCB-PRP could be a new therapeutic option for recovering the motor function and axonal regeneration after spinal cord injury.

\section{Highlights}

1-SCl induces motor dysfunction and apoptosis in rat spinal cord tissue.

2- Intraspinal injection of HUCB-PRP improves motor function recovery.

3- HUCB-PRP exert their neuroprotective effects by inhibiting apoptosis and GSK3 $\beta$ enzymes.

\section{Introduction}

Spinal cord injury $(\mathrm{SCl})$ is one of the very complicated and devastating clinical problems with constant neurological weakness, which causes due to inhibitory natural barriers of axonal growth cones and intrinsic insufficient growth capacity of the central nervous system (CNS) (1). Nowadays, the estimation of the lifetime cost of an $\mathrm{SCl}$ patient is $\$ 2.35$ million per patient (2). Therefore, finding efficient and new strategies to treat $\mathrm{SCl}$ is still one of the most important clinical challenges.

The pathology of the spinal cord after the injury is not yet well understood, but the primary and secondary phases after the injury have been proven. The primary phase of the injury begins immediately after the injury and is accordance with release of inflammatory factors which results to large neural cell death. But 
various pathophysiological events happen in the secondary phase of injury such as apoptosis, microglial activation, demyelination, and axonal degeneration. During the second phase after injury Wallerian degeneration in the spinal tract results in the loss of sensory and motor neuron functions $(3-5)$

Therefore, axonal regeneration is a necessary step to recover the injury. But axons in the adult CNS regenerate hardly, and this has been the reason for the failure of many treatments to date. Basically, different therapeutic strategies were concentrated on the inhibition of the apoptotic and necrotic cell death in the injured spinal cord and preparing an appropriate condition to promote axonal regeneration. The suitability of growth factors (GF), especially the neurotrophic factors, to reach these aims has been investigated by previous studies (6-9). All of them have shown that growth factors were induced axonal regeneration, remyelination, and motor function recovery and inhibited apoptosis.

For example, Transforming growth factor- $\beta$ (TGF- $\beta$ ) improves the synthesis of extracellular matrix components and promotes neuron survival (10). Insulin like growth factor-I (IGF1) specifically enhances the outgrowth of corticospinal motor neuron's axons in vitro (9). platelet-derived growth factor (PDGF) protects neurons by suppressing N-methyl-D-aspartic acid current and translocating the glutamate transporter to the cell membrane (11).

The problem is the short half-life of growth factors. To combat this problem intravenous injection of recombinant proteins, transplantation of cells secreting GF and viral gene delivery methods were used. These methods successfully improve motor function and increase axonal regeneration post-SCl in animal models. However, they do not have the necessary safety for clinical use because the immunogenicity (12-14). Today, researchers pay special attention to platelet-rich plasma (PRP) for the treatment of the injured CNS. The autologous PRP is non-toxic with easy-to-collect that does not cause an immune response. PRP contains millions of platelets per microliter which is more than the platelet density of normal blood. a-granules of platelets have abundant growth factors including vascular endothelial cell growth factor (VEGF), brain-derived neurotrophic factor (BDNF), glioblastoma-derived neurotrophic factor (GDNF), nerve growth factor (NGF), hepatocyte growth factor, PDGF, IGF, and TGF- $\beta$ (14). On the other hand, PRP is a rich source of GFs that can synergistically amplify each other's effects, and make each other more sustainable $(7,8,15)$. PRP shows beneficial properties in different fields of medicine such as oral and maxillofacial bone grafting procedures, healing wounds $(16,17)$, plastic surgery $(18)$, oral surgery, dentistry and ophthalmology (19). It has also been indicated to have beneficial effects on the growth, neuroprotection, anti-apoptosis and regeneration of peripheral nerves such as the sciatic nerve (20-22), facial nerve $(23)$ and the cavernous nerve $(24,25)$. The studies have examined the effect of PRP in peripheral blood on axonal regeneration and remyelination of the SCI models $(14,26-30)$. Studies indicated that the existence of numerous growth factors such as FGF, EGF, VEGF, IGF-1, interleukins and interferons in PRP is responsible for inducing many of its beneficial effects (31).

Human umbilical cord blood (HUCB) is also abundant and can be obtained by non-invasive methods and has none of the ethical issues related to other adult human resources (32). These clinical benefits included easy access to transplantation, relatively low incidence of GVHD (Graft-Versus-Host-Disease) 
(33). The platelets count in HUCB is higher than in peripheral blood (34). HUCB Platelet-rich plasma (HUCB-PRP) has a higher amount of GFs such as vascular fibroblast growth factor (FGF), VEGF, IGF-1 and epidermal growth factor (EGF), interleukins and interferons than peripheral blood, which are used for cell growth, proliferation and differentiation in fetal blood (31). Given our knowledge of related articles, there are few studies that have investigated the effect of PRP injections on injured spinal cords and activation of intrinsic mechanisms $(14,26,35)$. In this study, we investigated the effect of intraspinal injection of HUCB-PRP on the improvement of motor function and the expression of proteins affecting decreases wallerian degeneration and axonal stability.

\section{Methods}

\section{animals}

Adult male Wistar rats (weighing 150-185 g; n=10 per group) were randomly allocated into the experimental groups (Table 1). Experimental research made in accordance with the guidelines on laboratory animals of the Iran university of medical sciences and approved by the ethics committee (IR.IUMS.FMD.PEC.1398.037). The animals were kept under standard housing conditions $\left(21 \pm 1^{\circ} \mathrm{C}\right.$ and 12 hours' light-dark cycle) with pellet food and water provided ad libitum. Also, animal weight was measured before induction of injury and at the end of the sixth week (Table 1). The injured animals were kept separately and were sprayed by OTC to prevent infection after the surgery.

Table 1: The experimental groups. HUCB-PPP: Human umbilical cord blood Platelet-poor plasma, HUCBPRP: Human umbilical cord blood Platelet-rich plasma; SCl: spinal cord injury

\begin{tabular}{|c|c|c|c|}
\hline $\begin{array}{l}\text { Study } \\
\text { Groups }\end{array}$ & Treatment & $\begin{array}{l}\text { Weight of animals } \\
\text { before SCl ( mean } \\
\pm \text { SEM; } n=10)\end{array}$ & $\begin{array}{l}\text { Weight of animals in } \\
\text { the end study ( } \text { mean } \\
\pm \text { SEM; } n=10 \text { ) }\end{array}$ \\
\hline Control & Healthy animals & $170.61 \pm 4.06$ & $329.21 \pm 6.01$ \\
\hline $\begin{array}{l}\text { Sham } \\
\text { injection }\end{array}$ & $\begin{array}{l}\text { Removing the lamina with no injury to the } \\
\text { spinal cord }+ \text { inserting the micropipette } \\
\text { intraspinally at } 4 \text { points }\end{array}$ & $175.88 \pm 4.35$ & $334.9 \pm 8.94$ \\
\hline $\mathrm{SCl}$ & Removing the lamina $+\mathrm{SCl}$ induction & $171.93 \pm 3.8$ & $276.19 \pm 14.13$ \\
\hline Vehicle & $\begin{array}{l}\mathrm{SCl} \text { induction }+ \text { injection of HUCB-PPP } \\
\text { intraspinally at } 4 \text { points on the second } \\
\text { day after SCl }\end{array}$ & $169.65 \pm 3.41$ & $300.51 \pm 12.07$ \\
\hline $\begin{array}{l}\text { PRP } 2 \\
\text { day }\end{array}$ & $\begin{array}{l}\mathrm{SCl} \text { induction }+ \text { injection of HUCB-PRP } \\
\text { intraspinally at } 4 \text { points on the second } \\
\text { day after SCl }\end{array}$ & $172.88 \pm 3.29$ & $307 \pm 1259$ \\
\hline $\begin{array}{l}\text { PRP } 14 \\
\text { day }\end{array}$ & $\begin{array}{l}\mathrm{SCl} \text { induction }+ \text { the injection of HUCB-PRP } \\
\text { at } 4 \text { points Intraspinally on the fourteen } \\
\text { day after SCl }\end{array}$ & $172.29 \pm 2.84$ & $318 \pm 15.49$ \\
\hline
\end{tabular}




\section{HUCB-PRP preparation}

The HUCB-PRP obtained from a Blood Transfusion Organization (Tehran, Iran). The protocol used for platelet isolation was as follows:

PRP was separated from the blood by two-stage centrifugations at $1500 \mathrm{rpm}$ for 10 minutes in $4{ }^{\circ} \mathrm{C}$ and then $2200 \mathrm{rpm}$ for 10 minutes. After this stage, Platelets precipitate and the upper phase used as plateletpoor plasma (PPP) for injection to the vehicle group. Then the precipitate of platelets was suspended in $0.5 \mathrm{ml}$ of plasma and freshly used for injection in treatment groups. The platelet concentration was calculated by an automatic counter (Model Sysmex X-S 800i; Kobe, Japan).

\section{Surgical procedure and HUCB-PRP injection}

Surgery was done under intraperitoneal injection of ketamine $(100 \mathrm{mg} / \mathrm{kg})$ and xylazine $(10 \mathrm{mg} / \mathrm{kg})$ anaesthesia. After induction of incision in the skin, the back musculature was pushed aside at the midline, and a laminectomy was performed at the junction between the T12 and T13 vertebrae (in line with L2-L3 spinal segment). The last rib was as a guideline for confirming injury site. Because it is at the junction with the T13 vertebra (36). Then moderate spinal cord injury was created by calibrated aneurysm clip (force=20gr/cm2; for the 90s; FST company). The muscles and skin were sutured. Rats received tetracycline spray on the injured site to avoid infection and \%70 alcohol spray in the cage daily for one week and bladder emptying was performed until the return of the bladder control reflex. The Basso, Beattie, and Bresnahan (BBB) locomotor scale were performed $48 \mathrm{~h}$ after the surgery to confirm the loss of motor function in the $\mathrm{SCl}$ rats. Tumor or bone formation was not observed in any of the animals in our experiment.

The intraspinal injection of HUCB-PRP on the second and fourteen days after induction of SCl were done on the total volume of $6 \mu \mathrm{L} / 4$ locations in the spinal cord with coordinates $0.5 \mathrm{~mm}$ lateral from the midline in the depth of $1 \mathrm{~mm}$ from the surface. The rate of injection was $1 \mu \mathrm{l} / \mathrm{min}$. At the time of injection, the animals were anesthetized with Ketamine and Xylasin. The skin, muscle and adherent tissue were carefully separated. After determining the spinal cord levels, the animal was fixed in a stereotaxic device. Approximately, $6095426.58 \pm 266778.13$ platelets were drawn by Hamilton's syringe. Then the needle was inserted into a glass micropipette (with the tip diameter of about $30 \mu \mathrm{m}$ ) and fixed in the stereotaxic device. The micropipette inserted to the spinal cord. After injection of PRP, the micropipette remained in its place for two minutes for preventing PRP leakage. The above method was also used for vehicle animals, which received HUCB-PPP (351489.92 \pm 88185.41 platelets) on the second day post SCI.

\section{The evaluation of open-field locomotor scale}

The 21-point Basso-Beattie-Bresnahan (BBB) locomotion scale was used to assess the locomotor behavior recovery after $\mathrm{SCl}$. Based on the movement of joints, weight-bearing, placement of paws and coordination of paw and hind limbs (37), the hind-limb motor function was assess every week until the end of the study (six weeks follow-up). For this reason, each animal was monitored for 4 min in a cylinder 
with the $24 \mathrm{~cm}$ height and $90 \mathrm{~cm}$ diameter. The BBB scores were calculated by independent examiners who were not aware of the experimental groups and the mean scores were used in the analysis (38). The BBB assessment was performed before and after $\mathrm{SCl}$ induction. The BBB assessment was performed before $\mathrm{SCl}$ induction and conducted weekly after injury for six weeks

\section{Cerebrospinal fluid (CSF) collection}

Obtaining CSF through cisterna magna is a routine method in our Center for experimental and comparative studies. Animals were anaesthetized with the same dose of ketamine and xylazine and their head skin was shaved. The rats were fixed by the ear bars of the stereotaxic frame and were placed the head at an angle of $90^{\circ}(n>5)$. After the incision of the skin, the muscles were pushed aside to expose the cisterna magna membrane, Then the plunger of the insulin syringe was pulled slightly and inserted into the device. The needle was perpendicularly entered to cisterna magna until the beveled edge (between 0.5 and $1 \mathrm{~mm}$ ). The pressure difference pulled CSF to the syringe and then the plunger of the syringe was gently pulled. The maximum volume of CSF collected was 210 microliters. Then the clear CSF is transferred into Eppendorf tubes and stored at $\_80^{\circ} \mathrm{C}$.

\section{Tissue evaluation}

For tissue assessment, the animals were deeply anaesthetized with ketamine $(100 \mathrm{mg} / \mathrm{kg}, \mathrm{IP})$ and xylazine (10 mg/kg, IP) 6 weeks after surgery ( $\mathrm{n}=3$ per group).

The spinal cord was cleaned of blood by transcardial perfusion of normal saline and then was fixed by 4\% Paraformaldehyde $(\mathrm{pH}=7.2-7.4)$. Then vertebral columns were dissected and post fixed in $4 \%$ paraformaldehyde for 24 hours. The dissection was made in the larger area of T12-T13 vertebra levels (site of injury) to prevent extra injury to the level of the spinal cord. The L2-L3 level of spinal cord was held by paraffin wax (36). The sections with $5 \mu \mathrm{m}$ diameter were prepared for the immunohistochemically technique.

\section{Antibodies and reagents}

MAG and Tau antibody were obtained from the biorbyt Company (Cambs, UK)). GSK3 $\beta$, $\beta$-actin antibody, Anti-rabbit IgG HRP-linked Antibody were purchased from Santa Cruz Biotechnology Company (Santa Cruz, CA, United States). Caspase3 antibody was purchased from the Cell Signaling Technology company. Rabbit SpecificHRP/DAB (ABC) was prepared by the Abcam Company (Cambridge, UK).

\section{Immunohistochemistry}

At the day of experiment, deparaffinized and hydrated longitudinal sections were boiled in $0.1 \mathrm{M}$ sodium citrate buffer for $10 \mathrm{~min}$ to perform the heating antigen retrieval, then the sections were washed three times with PBS, Triton X-100/10\% and subsequently blocked with $10 \%$ normal goat serum or with $1 \%$ BSA in TBS for $2 \mathrm{~h}$ at room temperature. After washing, The primary Rabbit monoclonal antibodies capases 3 (cat. no. 14220) were diluted (1/100) in blocking solution overnight at $4{ }^{\circ} \mathrm{C}$ and the next day were 
incubated with goat antirabbit diluted in PBS/0.3\% BSA for $1 \mathrm{~h}$. Then they were incubated with enough Streptavidin-HRP (pink) for 10 minutes. Then enough DAB was added to the washed slides. After optional counterstain and dehydration, cover slips were done. Finally, for calculating the density of caspase3, three sections from the beginning, middle and the end of the injured location of the spinal cord ( $\mathrm{N}=3$ each group) were selected. Then five fields of the dorsal surface in each section were randomly selected, the density of caspase3 expression in each section was calculated as follows.

The density at each area $=$ the density of DAB stain at an area $/$ The area of the section

The final density of caspase 3 expression = the total density of DAB substrate (caspase3 expression) in five areas $/ 5$

The mean of density in all three sections is calculated for each animal.

\section{Protein extraction of spinal cord tissue and CSF for western blotting}

To assay the effect of HUCB-PRP injection on proteins the western blot (WB) technique at 6 weeks after injury were performed. For this purpose, the animals were anesthetized with the same dose of ketamine and xylazine ( $\mathrm{n}=4$ per group). Fresh spinal cord containing the injury location ( $5 \mathrm{~mm}$ in length) quickly dissected carefully and immediately transferred to ice and stored at $-80^{\circ} \mathrm{C}$ before performing the Western blotting. For the extraction of protein, $300 \mu \mathrm{l}$ of RIPA buffer was used for every $100 \mathrm{mg}$ of tissue. RIPA buffer was contained $10 \mu$ of all three enzymes: PMSF, Protease inhibitor cocktail, Sodium orthovanadate. Tissues were homogenized on the ice and were centrifuged $\left(13,000 \mathrm{~g}, 30 \mathrm{~min}, 4^{\circ} \mathrm{C}\right)$. The supernatants were collected and protein concentrations assayed by using the nanodrop equipment (Thermo Science, USA).

The protein concentrations of CSF were directly assayed by using the Nano drop equipment. The total concentrations of proteins in the CSF and in the supernatants of the spinal cord tissue are expressed in the table 2 .

Table 2: The total concentrations of proteins in the CSF and supernatants of the spinal cord tissue 


\begin{tabular}{|c|c|c|}
\hline $\begin{array}{l}\text { Study } \\
\text { Groups }\end{array}$ & $\begin{array}{l}\text { Protein concentration in spinal cord tissue (mean } \pm \\
\text { SEM; } \mathrm{n}=4 \text { ) } \\
\mathrm{mg} / \mathrm{ml}\end{array}$ & $\begin{array}{l}\text { Protein concentration in } \\
\text { CSF } \\
\text { (mean } \pm \text { SEM) } \\
\mathrm{mg} / \mathrm{ml}\end{array}$ \\
\hline Control & $18.83 \pm 3.08$ & $3.08 \pm 0.179$ \\
\hline $\begin{array}{l}\text { Sham } \\
\text { injection }\end{array}$ & $25.56 \pm 3.7$ & $3.32 \pm 0.165$ \\
\hline $\mathrm{SCl}$ & $18 \pm 1$ & $3.18 \pm 0.185$ \\
\hline Vehicle & $12.83 \pm 4.28$ & $3.49 \pm 0.382$ \\
\hline PRP 2 day & $12.48 \pm 1.63$ & $3.35 \pm 0.103$ \\
\hline PRP 14 day & $14.33 \pm 4.86$ & $3.69 \pm 0.118$ \\
\hline
\end{tabular}

\section{Western blotting:}

Equal amounts of supernatant tissue and CSF proteins $(50 \mu \mathrm{g})$ were electrophoresed in 10 SDSpolyacrylamide gel electrophoresis, and then the proteins were transferred to polyvinylidene difluoride membranes (PVDF) (Time: 25 min, voltage: $15 \mathrm{~V}$ ). The membranes were blocked with a fresh blocking buffer (containing 5\% skim milk and $0.1 \%$ Tween-20 in Tris-buffered saline, $\mathrm{pH} 7.4$ ) for $2 \mathrm{~h}$, and then the membranes incubated with specific primary antibodies GSK3 $\beta$ antibody (1:200, sc-81462), Tau antibody (1/1000, orb158145, MW: 52/79 kDa), MAG antibody (1/1000, orb536682, MW: 63 kDa), $\beta$-actin antibody (1:500, sc-47778, MW:45KD) in blocking buffer overnight at $4{ }^{\circ} \mathrm{C}$ overnight at 4 . After three washes with TBST, the blots were incubated with horseradish peroxidase conjugated IgG (1/1000, sc-516102) for $2 \mathrm{~h}$. Protein bands on the membranes were detected by enhanced chemiluminescence (ECL) and exposed by the ChemiDoc Imaging System. The $\beta$-actin antibody was used to normalize the western blot bands. Band intensity was measured quantitatively and analyzed by Image $\mathrm{J}$ software.

\section{Statistical analysis}

All the evaluations have been performed blindly without aware of animals grouping. SPSS 22.0 and Graph Pad Prism 8.0 was used for statistical assessment of the data (mean \pm SEM). The one-way ANOVA followed by a Tukey post-hoc test was used for analysis the data of western blot and immunohistochemistry methods, and the repeated-measure ANOVA with a Bonferroni post hoc test was used for comparison of the BBB scores between different groups. $p<0.05$ was considered as significant.

\section{Results}

In this study, dead animals or animal with rotational motion were excluded from the study. These rats were replaced and the data from 60 animals were used in the analysis. 


\section{The intraspinal injection of HUCB-PRP improves locomotion recovery function.}

Initial evaluation of SCl locomotor recovery was carried out using the BBB scale which has been shown to be useful in evaluating post-SCl function in rats. The score (0-21) represents different combinations of joint movements, coordination, paw placement, and toe clearance where a higher score represents a better functional motor recovery. Significant differences in the mean score between the HUCB-PRP-treated groups and no-HUCB-PRP group ( $\mathrm{SCl}$ and vehicle groups) represents improvement in the movement of injured animals $(d f=30.324 ; F=59.63 ; p<0.0001)$.

The BBB score for animals that received HUCB-PRP on the second days after SCl had the best locomotor function recovery (with a mean initial BBB score of $8.7 \pm .597$ in the first week and a mean BBB score of $15.15 \pm 0.5377$ in week 6$)$ than the SCl group $(p<0.0001)$ and vehicle group $(P=0.0042)$.

Improvement of the BBB score for animals which received platelets after 14 days (PRP 14 day), started two weeks after injection of PRP with a mean initial score of $5.7 \pm 0.27$ and was significantly different versus the $\mathrm{SCl}$ group at the end study $(\mathrm{p}<0.0001)$. The recovery process in PRP 14 -day group showed a slower recovery rate than in the PRP2 day group until the end of study. There was a significant difference between the PRP2 day and PRP 14-day group. It is noteworthy that the motor function score in the both groups injected with PRP was still lower than healthy animals up to the end of the study $(p<0.0001)$ (Figure 1).

\section{HUCB-PRP decreased caspase 3 expression, as an apoptosis marker in injured animals}

The statistical result showed a significant difference in caspase 3 expression between groups at the end of the study ( $d F=5 ; F=18.852 ; p<0.0001)$. At 6 weeks postoperatively, immunohistochemical technique showed an obvious increase in the caspase 3 expression in the SCI $(58.947 \pm 1.01 ; p<0.0001)$ and vehicle $(52.537 \pm 5.72 ; p<0.0001)$ groups versus the control animals. Indicating that the injury increased apoptosis process and plasma without sufficient platelet concentration has no improving effect on the caspase3 expression (vehicle group). Significant decrease in caspase3 expression observed in animals which received PRP on the second and fourteenth day after injury (43.426 $\pm 1.28 ; p=0.02$ and $45.26 \pm 0.584$; $\mathrm{p}=0.043$ respectively) compared to the $\mathrm{SCl}$ groups. Also there was a significant difference in the caspase 3 expression between both HUCB-PRP-treated groups and the control group at 6 weeks postoperatively $(p=0.004$ and $p=0.002$ respectively) (Figure 2$)$.

\section{HUCB-PRP decreased glycogen synthase kinase-3 $\beta$ (GSK3 $\beta$ ) expression as an inducer of apoptosis and axonal degeneration in injured animals}

The statistical result showed a significant difference in GSK3 $\beta$ expression between groups at 6 weeks post-SCl $(d f=5 ; F=4.704 ; p=0.013)$. At the end of the study, an obvious increase in GSK3 $\beta$ expression in the $\mathrm{SCl}$ group $(1.35 \pm 0.116 ; p=0.027)$ versus the control group $(0.822 \pm 0.049)$ was observed which indicated that the $\mathrm{SCl}$ increased the inducer of apoptosis and axonal degeneration. The expression of 
GSK3 $\beta$ in animals which received HUCB-PRP on the second and fourteenth day after injury $(0.792 \pm 0.119$; $p=0.018$ and $0.83 \pm 0.075 ; p=0.029$ respectively) was significantly decreased compared with the $S C I$ groups. There was no significant difference between both PRP-treatment groups and the control group at 6 weeks postoperatively (Figure 3 )

\section{HUCB-PRP decreased the tau expression in CSF as a biomarker of axonal degeneration in injured animals}

The statistical analysis showed a significant difference in the tau expression in CSF between groups at the end study ( $d f=5 ; F=7.655 ; p=0.002)$. At the sixth week after injury the tau expression significantly increased in the $\mathrm{SCl}$ animals $(3.89 \pm 0.372 ; \mathrm{p}=0.001)$ compared to the control animals $(0.372 \pm 0.117)$ indicating that The axons severely degenerated in the injured group and the tau protein separated from the microtubules and leaked into the CSF.

The total tau expression in animals which received HUCB-PRP on the second and fourteenth day after injury (1.128 $\pm 0.227 ; p=0.009$ and $1.044 \pm 0.315 ; p=0.008$ respectively) significantly decreased compared with the $\mathrm{SCl}$ groups. There was no significant difference between both PRP-treatment groups and the control group on sixth week postoperatively (Figure 4).

\section{HUCB-PRP increased the MAG expression of spinal cord in injured animals}

The statistical result showed a significant difference in MAG expression between groups at 6 weeks post$\mathrm{SCl}(\mathrm{df}=5 ; \mathrm{F}=9.334 ; \mathrm{p}<0.0001)$. Six weeks after injury a significant decrease observed in MAG expression in the $\mathrm{SCl}(0.8 \pm 0.358 ; p=0.009)$ and the vehicle group $(1.09 \pm 0.282 ; \mathrm{p}=0.037)$ versus the control group (2.55 \pm 0.281$)$. This decrease in the level of MAG expression was compensated by injection of HUCB-PRP and in animal which received HUCB-PRP on the second and fourteenth day after injury $(2.57 \pm 0.227$; $p=0.008$ and $3.24 \pm 0.399 ; p<0.0001$ respectively) the expression level increased compared with the $\mathrm{SCl}$ groups. There was no significant difference between both PRP-treatment groups and the control group at 6 weeks postoperatively (Figure 5).

\section{Discussion}

In this experiment, the clip compression injury model was chosen since the symptoms of injury in the acute stage are quite similar to spinal cord injury at the time of the accident, and in chronic conditions, glial scars form in the spinal cord, which was quite similar to patients with spinal cord injury (39). Our study reported for the first time the effect of PRP in human umbilical cord blood on spinal cord injury. HUCB-PRP was chosen because it provides easier access, lower sensitivity, longer durability, low immunogenicity and most importantly, richer growth factors such as PDGF, FGF-2, VEGF than adult PRP $(31,40-43)$. Umbilical cord blood is less exposed to environmental pathogens and vaccines compared with adults' blood and it has a high ratio of T cells (44) and a lesser amount of inflammatory factors (45).

Our statistical analysis indicated that injury to the spinal cord decreased locomotor function recovery and the expression of MAG protein in spinal cord tissue, and increased expression of capase3, GSK3 $\beta$ and 
CSF-tau proteins and treatment with HUCB-PRP compensated these alterations. Spontaneous recovery happened at a slow-rate until the end of the study in the $\mathrm{SCl}$ group which confirms the correctness of our model. Spontaneous recovery is mostly happen due to local structural rearrangements, such as collateral sprouting from remaining axons in gray matter than the regeneration of axons in white matter (46). In our study, the induction of apoptosis and axonal degradation may be the cause of motor disability in the $\mathrm{SCl}$ animals.

Under normal conditions, there is a balance between the pro-apoptotic factors and the anti-apoptotic factors which disrupted during injury and promotes the cell death. Caspase3 is a definite factor in promoting apoptosis. Apoptosis exerts its effects via two main apoptotic pathways depended on caspase 3: the extrinsic or death receptor pathway, the intrinsic or mitochondrial pathway. Since caspase 3 production, is the starting point of the executive phase of apoptosis, it is considered the principal indicator of apoptosis (47). It is believed that apoptosis is the main factor in the loss of motor neuron functions after injury $(3-5,48)$. In our experiment the existence of big cavity size in the $\mathrm{SCl}$ and vehicle groups confirm degeneration in the site of injury (Fig. 2). Oligodendrocytes and Schwan cells are the source of storage and release of Myelin-associated glycoprotein (MAG) protein and play an important role in the myelination of motor fibers axons (49). Its function is the maintenance of myelinated axons (49), inducing axon durability and entirety, and protection of axons under pathological conditions (50, 51). MAG stimulates axonal growth of young neurons and in the opposite role, suppresses the growth of older neurons in the adult CNS. This shift of function depends on age, developmental stage and type of the neurons $(52,53)$. Genetically deleting MAG decreased the axonal sprouting in the corticospinal tract $(54,55)$. Apoptosis induced oligodendrocyte destruction at 2 to 3 weeks post-SCI $(56,57)$.

Oligodendrocytes are particularly susceptible to environment toxicity after $\mathrm{SCl}$. They stand both necrosis and apoptosis in the acute phase, and their destruction continues with apoptosis at the chronic phase. Since oligodendrocytes are the main source of MAG in CNS, apoptosis of oligodendrocyte reduces MAG protein.

Also, in our study, the level of GSK3 $\beta$ increased following injury to the spinal cord. GSK-3 $\beta$ is a major member of the Wnt pathway. The Wnt pathway is the one of most important cascade in the nervous system. Evidence has shown that dis-regulation of the Wnt pathway causes pathogenic signals in neurodegenerative diseases (58). It has been shown that injury to the spinal cord causes the dysfunction of motor system in three ways: 1 ) the induction of the apoptotic process with caspase 3 expression (59, 60). 2) the activation of GSK3B-MCL1 pathway as a basic factor for Wallerian degeneration which results in axonal degeneration (61) and 3) hyperphosphorylation of Tau and neurodegeneration (62).

Phosphorylated tau is observed in the primary stages of neurodegenerative diseases (58). Tau is a neuronal microtubule-associated protein and in normal condition has a role in microtubule stabilization or the regulation of axonal transport. In many cases, tau phosphorylation results in isolation from microtubules and induce tau toxicity (63). Also, The presence of phosphorylated tau in the cerebrospinal fluid is a biomarker for the severity of CNS injuries such as Multiple Sclerosis (64), $\mathrm{SCl}$ (65) and Alzheimer's disease (66). The dysfunction of Tau protein could play a vital role in the development of the 
injury in $\mathrm{SCl}$ situation (67). It has been reported that the hyperphosphorylation of tau by GSK3 in dendritic spines damages the synaptic activity (68).

Our data showed that HUCB-PRP treatment improved the motor function, but did not recover it completely. The reason for this difference could be due to inhibitory natural barriers for axonal growth cones in mature neurons and intrinsic insufficient growth capacity of CNS (1). Also, HUCB-PRP dramatically increased MAG expression and decreased GSK3 $\beta$, caspase3 and CSF-tau levels compared to the injury group. Previous studies showed that PRP promoted or/and help axonal regeneration and sprouting of axons in the SCI models $(14,26-30,69)$. Similar to the results from Salarinia's study (29) we showed that PRP injection reduced apoptosis which resulted in an increased in the MAG level and reduction in the destruction of oligodendrocytes. However, some studies have not indicate any appreciable changes in the content of MAG in the early and later stages of central Wallerian degeneration (70). PRP is rich in the growth factors which each of them has beneficial effects on cell growth and survival. Some of growth factors in PRP assist in the repair processes after the injury and play a role as a catalyst for improving the repair ability of regenerating fibers. It has been shown that IGF-1 and NGF are able to increase the axonal growth of motor neurons in vitro and in vivo respectively (9). Sharma et. al showed that the use of BDNF, GDNF, and IGF-1 alone or in combination reduced blood-spinal barrier failure, edema, and cell damage in rats with spinal cord injury, although treatment is more effective when growth factors were combined $(7,8)$. Also, BDNF and GDNF have significantly improved motor function(8). In another study, revealed that combined PDGF and IGF-I did not recover sciatic nerve regeneration in a transaction and anastomosis model (71). Also, an NGF administration develops the motor function and induce the survival of the neurons in the SCl. NGF diminishes neuronal apoptosis by inhibition the caspase-3 cascade (72). Some study showed that NGF (73) and IGF-I has neuroprotective effects that are done through activating Akt, inhibiting GSK-3 $\beta$ subsequently reducing tau hyper phosphorylation in vivo (74) and invitro (75). If these factors are applied locally just once, their effects on recovery will not be exerted sufficiently. To increase their function, they must be applied several times or applied by some additional methods (used of fibrin sealant clots, foams, organic/synthetic tubes, and osmotic pumps) (76-78). However, PRP is the combination of growth factors that boosts the synergy effects $(7,8)$. We did not check the composition and concentration of the growth factors in the HUCB-PRP and this is the limitation of our study. It has previously mentioned that PRP delivered from umbilical cord has richer growth factors than adult PRP $(31,40)$. A few studies have examined the effect of PRP on axonal regeneration and remyelination of the spinal cord injury models $(14,26-30)$.

In 2012, Takeuchi et al, the first time used a rat organ co-culture system (brain-spinal cord co-culture) to estimate the ability of PRP to stimulate the axonal growth in spinal cord tissues and identified the growth factors in PRP that contribute to the regulation of the axonal growth. They found that PRP enhanced the axonal growth in the spinal cord tissues through mechanisms related to IGF-1 and VEGF, while TGF- $\beta 1$ in PRP exerted destructive effects on the axonal growth (35). In another study, Salarinia et. al. showed that PRP injection 24 hours and one week after spinal cord injury improves motor function and increases axonal repair (26). He also showed that combined use of platelet-rich plasma and adipose tissue-derived mesenchymal stem cells has a synergistic effect on motor function recovery by inhibiting the caspase 3 
pathway (29). Chen et al.'s study indicated that intrathecal PRP injection caused neuronal regeneration (14). Also in 2020, a study stated that in chitosan scaffolds filled with PRP and human endometrial stem cells (hEnSCs), PRP increased the survival of hEnSCs cells and prevented the formation of scare tissue. It also was responsible for angiogenesis and regeneration of the nerve fibers (28).

The results of our experiment are in agreement with previous studies $(14,26,29,48)$.

We propose the following mechanism for the effectiveness of HUBC-PRP on motor function recovery after SCl (Fig. 6).

1) Oligodendrocyte aapoptosis decreases MAG expression and induces Wallerian degeneration. PRP improves axonal regeneration and sprouting in nerves via suppressing the caspase3 enzyme and reducing apoptosis $(35,79)$. Sprouting is a naturally occurring repair mechanism $(80)$. Studies have shown that during sprouting of healthy axons, MAG secretion increases to inhibit ectopic sprouting of axons and modulates the sprouting process $(53,80)$, and supports axons from later degeneration in the adult CNS (81). But the effect of MAG on the regeneration of injured axons is limited (80). Also, the study showed that only after damage of the myelin and axonal attempt for regeneration, MAG is released and affect the growth cones (81).

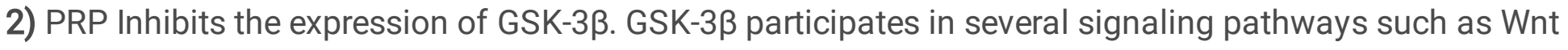
signaling pathway and apoptosis. It has been shown that GSK-3 inhibitors regenerated injured neuronal fibers and functional recovery in rats with spinal cord injury (82). Reducing the GSK-3 levels promotes axonal elongation and branching in cortical and hippocampal neurons (83). Also, apoptosis was diminished by inhibiting GSK-3 $\beta$ in primary neurons (84). On the other hand, PRP boosts contact between Tau protein and microtubule by inhibiting GSK-3 $\beta$ expression. Therefore, Tau maintains the stability of microtubules in the spinal cord axons. As a result, Tau repairs axonal transport and synaptic dysfunctions.

The other possibility of beneficial effect of PRP injection could be through mTOR signaling pathway. Our previous study indicated that HUCB-PRP increases mTOR signaling (69). MTOR signaling (as an upstream protein for apoptosis and GSK-3 $\beta$ ) regulates central neuronal myelination and oligodendrocyte differentiation $(85,86)$ and inhibits apoptosis $(87)$ and GSK3 $\beta$ expression (88).

Therefore, it seems that PRP could act through different mechanisms to help the central nervous system to prevent cell death and induce axonal regeneration and could be considered as a new treatment strategy in a situation with spinal cord injury.

\section{Conclusion}

Our results showed that intraspinal injection of HUCB-PRP could significantly improve motor function recovery after SCI. HUCB-PRP injection decreased caspases3, GSK3 $\beta$ and tau levels and increases MAG expression six weeks after injury. Our findings provide valuable information on the influence of a HUCB- 
PRP on alleviating SCI symptoms. Since HUCB-PRP has long durability and richer growth factors than adult PRP and because it does not stimulate the immune system responses it might provide a suitable therapeutic opportunity for axonal regeneration and motor function recovery after injury to the nervous system in human. However, more investigation is required to translate the results to the clinics.

\section{Declarations}

\section{authors' contributions:}

F.N: Designed the experimental and supervised the procedure. Z.B: Carried out the experimental, the statistics and wrote the manuscript under supervision of F.N.

F.R: Supervised and analyzed the western blot technique. All authors read and approved the final manuscript.

\section{Funding sources:}

The present study was a part of Ph.D. thesis that was financially supported by research affairs of Iran University of Medical Sciences [Project No. 97-02-30-33139] and Iran National Science Foundation [Project No. 97009811].

\section{Availability of data and material:}

Data are however available from Zahra Behroozi upon reasonable request.

\section{Ethics approval and consent to participate:}

Experimental research protocol on animals was approved by the ethics committee of Iran University of Medical Sciences (IR.IUMS.FMD.PEC.1398.037). All procedures were strictly conducted in accordance with the code of ethics.

\section{Consent for publication:}

All authors consented for publication.

\section{Competing interests:}

The authors declared that they have no competing interests.

\section{Acknowledgements:}

Not applicable

\section{References}


1. Leibinger M, Hilla AM, Andreadaki A, Fischer D. GSK3-CRMP2 signaling mediates axonal regeneration induced by Pten knockout. Communications biology. 2019;2(1):1-13.

2. Alizadeh A, Dyck SM, Karimi-Abdolrezaee S. Traumatic spinal cord injury: an overview of pathophysiology, models and acute injury mechanisms. Front Neurol. 2019;10:282.

3. Li GL, Brodin G, Farooque M, Funa K, Holtz A, Wang WL, et al. Apoptosis and expression of Bcl-2 after compression trauma to rat spinal cord. J Neuropathol Exp Neurol. 1996;55(3):280-9.

4. Barres B, Jacobson M, Schmid R, Sendtner M, Raff M. Does oligodendrocyte survival depend on axons? Curr Biol. 1993;3(8):489-97.

5. Crowe MJ, Bresnahan JC, Shuman SL, Masters JN, Beattie MS. Apoptosis and delayed degeneration after spinal cord injury in rats and monkeys. Nature medicine. 1997;3(1):73-6.

6. Mattson MP. Apoptosis in neurodegenerative disorders. Nature reviews Molecular cell biology. 2000;1(2):120-30.

7. Sharma H, Nyberg F, Westman J, Alm P, Gordh T, Lindholm D. Brain derived neurotrophic factor and insulin like growth factor-1 attenuate upregulation of nitric oxide synthase and cell injury following trauma to the spinal cord. Amino Acids. 1998;14(1):121-9.

8. Sharma HS. A select combination of neurotrophins enhances neuroprotection and functional recovery following spinal cord injury. Ann N Y Acad Sci. 2007;1122(1):95-111.

9. Özdinler PH, Macklis JD. IGF-I specifically enhances axon outgrowth of corticospinal motor neurons. Nature neuroscience. 2006;9(11):1371-81.

10. McTigue DM, Popovich PG, Morgan TE, Stokes BT. Localization of transforming growth factor- $\beta 1$ and receptor mRNA after experimental spinal cord injury. Exp Neurol. 2000;163(1):220-30.

11. Egawa-Tsuzuki T, Ohno M, Tanaka N, Takeuchi Y, Uramoto H, Faigle R, et al. The PDGF B-chain is involved in the ontogenic susceptibility of the developing rat brain to NMDA toxicity. Exp Neurol. 2004;186(1):89-98.

12. Peden CS, Burger C, Muzyczka N, Mandel RJ. Circulating anti-wild-type adeno-associated virus type 2 (AAV2) antibodies inhibit recombinant AAV2 (rAAV2)-mediated, but not rAAV5-mediated, gene transfer in the brain. Journal of virology. 2004;78(12):6344-59.

13. Marshall E. Second child in French trial is found to have leukemia. Science. 2003;299(5605):320-.

14. Chen N-F, Sung C-S, Wen Z-H, Chen C-H, Feng C-W, Hung H-C, et al. Therapeutic effect of platelet-rich plasma in rat spinal cord injuries. Front NeuroSci. 2018;12:252.

15. Wen Y-H, Lin W-Y, Lin C-J, Sun Y-C, Chang P-Y, Wang H-Y, et al. Sustained or higher levels of growth factors in platelet-rich plasma during 7-day storage. Clin Chim Acta. 2018;483:89-93.

16. Carter CA, Jolly DG, Worden Sr CE, Hendren DG, Kane CJ. Platelet-rich plasma gel promotes differentiation and regeneration during equine wound healing. Exp Mol Pathol. 2003;74(3):244-55.

17. Oyama T, Nishimoto S, Tsugawa T, Shimizu F. Efficacy of platelet-rich plasma in alveolar bone grafting. Journal of oral maxillofacial surgery. 2004;62(5):555-8. 
18. Sommeling C, Heyneman A, Hoeksema H, Verbelen J, Stillaert F, Monstrey S. The use of platelet-rich plasma in plastic surgery: a systematic review. Journal of Plastic Reconstructive Aesthetic Surgery. 2013;66(3):301-11.

19. Ronci C, Ferraro AS, Lanti A, Missiroli F, Sinopoli S, Del Proposto G, et al. Platelet-rich plasma as treatment for persistent ocular epithelial defects. Transfus Apheres Sci. 2015;52(3):300-4.

20. Izquierdo O, Alvarez R, Aparicio P, Castellanos J, Dominguez E, editors EFFECT OF PLATELET-RICH PLASMA ON PERIPHERAL NERVE REGENERATION. MODEL IN RAT. Orthopaedic Proceedings; 2011: The British Editorial Society of Bone \& Joint Surgery.

21. Sariguney $Y$, Yavuzer R, Elmas $C$, Yenicesu I, Bolay H, Atabay K. Effect of platelet-rich plasma on peripheral nerve regeneration. J Reconstr Microsurg. 2008;24(03):159-67.

22. Elgazzar R, Mutabagani M, Abdelaal S, Sadakah A. Platelet rich plasma may enhance peripheral nerve regeneration after cyanoacrylate reanastomosis: a controlled blind study on rats. Int $\mathrm{J}$ Oral Maxillofac Surg. 2008;37(8):748-55.

23. Malahias M-A, Chytas D, Babis GC, Nikolaou VS. Platelet-rich plasma guided injections: clinical application in peripheral neuropathies. Frontiers in surgery. 2014;1:41.

24. Ding X-G, Li S-W, Zheng X-M, Hu L-Q, Hu W-L, Luo Y. The effect of platelet-rich plasma on cavernous nerve regeneration in a rat model. Asian journal of andrology. 2009;11(2):215.

25. Wu YN, Wu CC, Sheu MT, Chen KC, Ho HO, Chiang HS. Optimization of platelet-rich plasma and its effects on the recovery of erectile function after bilateral cavernous nerve injury in a rat model. $J$ Tissue Eng Regen Med. 2016;10(10):E294-304.

26. Salarinia R, Sadeghnia HR, Alamdari DH, Hoseini SJ, Mafinezhad A, Hosseini M. Platelet rich plasma: Effective treatment for repairing of spinal cord injury in rat. Acta Orthop Traumatol Turc. 2017;51(3):254-7.

27. Zhao T, Yan W, Xu K, Qi Y, Dai X, Shi Z. Combined treatment with platelet-rich plasma and brainderived neurotrophic factor-overexpressing bone marrow stromal cells supports axonal remyelination in a rat spinal cord hemi-section model. Cytotherapy. 2013;15(7):792-804.

28. Ai J, Farzin A, Zamiri S, Hadjighassem M, Ebrahimi-Barough S, Ai A, et al. Repair of injured spinal cord using platelet-rich plasma-and endometrial stem cells-loaded chitosan scaffolds. International Journal of Polymeric Materials and Polymeric Biomaterials. 2020:1-10.

29. Salarinia R, Hosseini M, Mohamadi Y, Ghorbani A, Alamdari DH, Mafinezhad A, et al. Combined use of platelet-rich plasma and adipose tissue-derived mesenchymal stem cells shows a synergistic effect in experimental spinal cord injury. J Chem Neuroanat. 2020;110:101870.

30. Takenaga M, Ohta Y, Tokura Y, Hamaguchi A, Suzuki N, Nakamura M, et al. Plasma as a scaffold for regeneration of neural precursor cells after transplantation into rats with spinal cord injury. Cell Transplant. 2007;16(1):57-65.

31. Hashemi S-S, Mahmoodi M, Rafati AR, Manafi F, Mehrabani D. The role of human adult peripheral and umbilical cord blood platelet-rich plasma on proliferation and migration of human skin fibroblasts. World journal of plastic surgery. 2017;6(2):198. 
32. Gluckman E. History of cord blood transplantation. Bone marrow transplantation. 2009;44(10):6216.

33. Yun HD, Varma A, Hussain MJ, Nathan S, Brunstein C. Clinical Relevance of Immunobiology in Umbilical Cord Blood Transplantation. Journal of clinical medicine. 2019;8(11):1968.

34. Lee J-Y, Nam H, Park Y-J, Lee S-J, Chung C-P, Han S-B, et al. The effects of platelet-rich plasma derived from human umbilical cord blood on the osteogenic differentiation of human dental stem cells. In Vitro Cellular Developmental Biology-Animal. 2011;47(2):157-64.

35. Takeuchi M, Kamei N, Shinomiya R, Sunagawa T, Suzuki O, Kamoda H, et al. Human platelet-rich plasma promotes axon growth in brain-spinal cord coculture. Neuroreport. 2012;23(12):712-6.

36. Moonen G, Satkunendrarajah K, Wilcox JT, Badner A, Mothe A, Foltz W, et al. A new acute impactcompression lumbar spinal cord injury model in the rodent. J Neurotrauma. 2016;33(3):278-89.

37. Basso DM, Beattie MS, Bresnahan JC. A sensitive and reliable locomotor rating scale for open field testing in rats. J Neurotrauma. 1995;12(1):1-21.

38. Sarveazad A, Janzadeh A, Taheripak G, Dameni S, Yousefifard M, Nasirinezhad F. Co-administration of human adipose-derived stem cells and low-level laser to alleviate neuropathic pain after experimental spinal cord injury. Stem Cell Res Ther. 2019;10(1):183.

39. Cregg JM, DePaul MA, Filous AR, Lang BT, Tran A, Silver J. Functional regeneration beyond the glial scar. Exp Neurol. 2014;253:197-207.

40. Murphy MB, Blashki D, Buchanan RM, Yazdi IK, Ferrari M, Simmons PJ, et al. Adult and umbilical cord blood-derived platelet-rich plasma for mesenchymal stem cell proliferation, chemotaxis, and cryopreservation. Biomaterials. 2012;33(21):5308-16.

41. Rabian-Herzog C, Lesage S, Gluckman E. Characterization of lymphocyte subpopulations in cord blood. Bone marrow transplantation. 1992;9:64-7.

42. Bofill M, Akbar AN, Salmon M, Robinson M, Burford G, Janossy G. Immature CD45RA (low) RO (low) $T$ cells in the human cord blood. I. Antecedents of CD45RA + unprimed T cells. J Immunol. 1994;152(12):5613-23.

43. Cohen S, Madrigal J. Immunological and functional differences between cord and peripheral blood. Bone Marrow Transplant. 1998;21:9-12.

44. Reen DJ. Activation and functional capacity of human neonatal CD4 T-cells. Vaccine. 1998;16(1415):1401-8.

45. Gluckman E, Rocha V. History of the clinical use of umbilical cord blood hematopoietic cells. Cytotherapy. 2005;7(3):219-27.

46. Friedli L, Rosenzweig ES, Barraud Q, Schubert M, Dominici N, Awai L, et al. Pronounced species divergence in corticospinal tract reorganization and functional recovery after lateralized spinal cord injury favors primates. Science translational medicine. 2015;7(302):302ra134-4.

47. Jan R. Understanding apoptosis and apoptotic pathways targeted cancer therapeutics. Advanced pharmaceutical bulletin. 2019;9(2):205. 
48. Janzadeh A, Nasirinezhad F, Masoumipoor M, Jameie SB. Photobiomodulation therapy reduces apoptotic factors and increases glutathione levels in a neuropathic pain model. Lasers in medical science. 2016;31(9):1863-9.

49. Quarles RH. Myelin-associated glycoprotein (MAG): past, present and beyond. Journal of neurochemistry. 2007;100(6):1431-48.

50. Nguyen T, Mehta NR, Conant K, Kim K-J, Jones M, Calabresi PA, et al. Axonal protective effects of the myelin-associated glycoprotein. J Neurosci. 2009;29(3):630-7.

51. Kinter J, Lazzati T, Schmid D, Zeis T, Erne B, Lützelschwab R, et al. An essential role of MAG in mediating axon-myelin attachment in Charcot-Marie-Tooth $1 \mathrm{~A}$ disease. Neurobiol Dis. 2013;49:221-31.

52. Mukhopadhyay G, Doherty P, Walsh FS, Crocker PR, Filbin MT. A novel role for myelin-associated glycoprotein as an inhibitor of axonal regeneration. Neuron. 1994;13(3):757-67.

53. Lee JK, Zheng B. Role of myelin-associated inhibitors in axonal repair after spinal cord injury. Exp Neurol. 2012;235(1):33-42.

54. Lee JK, Geoffroy CG, Chan AF, Tolentino KE, Crawford MJ, Leal MA, et al. Assessing spinal axon regeneration and sprouting in Nogo-, MAG-, and OMgp-deficient mice. Neuron. 2010;66(5):663-70.

55. Bartsch U, Bandtlow CE, Schnell L, Bartsch S, Spillmann AA, Rubin BP, et al. Lack of evidence that myelin-associated glycoprotein is a major inhibitor of axonal regeneration in the CNS. Neuron. 1995;15(6):1375-81.

56. Li GL, Farooque M, Holtz A, Olsson Y. Apoptosis of oligodendrocytes occurs for long distances away from the primary injury after compression trauma to rat spinal cord. Acta Neuropathol. 1999;98(5):473-80.

57. Warden P, Bamber NI, Li H, Esposito A, Ahmad KA, Hsu CY, et al. Delayed glial cell death following wallerian degeneration in white matter tracts after spinal cord dorsal column cordotomy in adult rats. Exp Neurol. 2001;168(2):213-24.

58. Hadi F, Akrami H, Shahpasand K, Fattahi MR. Wnt signalling pathway and tau phosphorylation: A comprehensive study on known connections. Cell Biochem Funct. 2020;38(6):686-94.

59. Song L, De Sarno P, Jope RS. Central role of glycogen synthase kinase-3 $\beta$ in endoplasmic reticulum stress-induced caspase-3 activation. J Biol Chem. 2002;277(47):44701-8.

60. Carmichael J, Sugars KL, Bao YP, Rubinsztein DC. Glycogen synthase kinase-3 $\beta$ inhibitors prevent cellular polyglutamine toxicity caused by the Huntington's disease mutation. J Biol Chem. 2002;277(37):33791-8.

61. Wakatsuki S, Tokunaga S, Shibata M, Araki T. GSK3B-mediated phosphorylation of MCL1 regulates axonal autophagy to promote Wallerian degeneration. J Cell Biol. 2017;216(2):477-93.

62. Lucas JJ, Hernández F, Gómez-Ramos P, Morán MA, Hen R, Avila J. Decreased nuclear $\beta$-catenin, tau hyperphosphorylation and neurodegeneration in GSK-3 $\beta$ conditional transgenic mice. EMBO J. 2001;20(1-2):27-39. 
63. Avila J, Lucas JJ, Perez M, Hernandez F. Role of tau protein in both physiological and pathological conditions. Physiological reviews. 2004;84(2):361-84.

64. Szalardy L, Zadori D, Simu M, Bencsik K, Vecsei L, Klivenyi P. Evaluating biomarkers of neuronal degeneration and neuroinflammation in CSF of patients with multiple sclerosis-osteopontin as a potential marker of clinical severity. Journal of the neurological sciences. 2013;331(1-2):38-42.

65. Tang Y, Liu H-L, Min L-X, Yuan H-S, Guo L, Han P-B, et al. Serum and cerebrospinal fluid tau protein level as biomarkers for evaluating acute spinal cord injury severity and motor function outcome. Neural regeneration research. 2019;14(5):896.

66. Fossati S, Ramos Cejudo J, Debure L, Pirraglia E, Sone JY, Li Y, et al. Plasma tau complements CSF tau and P-tau in the diagnosis of Alzheimer's disease. Alzheimer's \& Dementia: Diagnosis, Assessment \& Disease Monitoring. 2019;11(1):483 - 92.

67. Nakhjiri E, Vafaee MS, Hojjati SMM, Shahabi P, Shahpasand K. Tau Pathology Triggered by Spinal Cord Injury Can Play a Critical Role in the Neurotrauma Development. Mol Neurobiol. 2020;57(11):4845-55.

68. Hoover BR, Reed MN, Su J, Penrod RD, Kotilinek LA, Grant MK, et al. Tau mislocalization to dendritic spines mediates synaptic dysfunction independently of neurodegeneration. Neuron. 2010;68(6):1067-81.

69. Behroozi Z, Ramezani F, Janzadeh A, Rahimi B, Nasirinezhad F. Platelet-rich plasma in umbilical cord blood reduces neuropathic pain in spinal cord injury by altering the expression of ATP receptors. Physiol Behav. 2021;228:113186.

70. Wender M, Wajgt A, Michałowska G, Tokarz E. Myelin associated glycoprotein (MAG) in Wallerian degeneration of the optic nerve. Experimental pathology. 1984;25(2):125-7.

71. Welch J, Kraus K, Wells M, Blunt D, Weremowitz J. Effect of combined administration of insulin-like growth factor and platelet-derived growth factor on the regeneration of transected and anastomosed sciatic nerve in rats. American journal of veterinary research. 1997;58(9):1033-7.

72. Zhang $\mathrm{H}$, Wu F, Kong $X$, Yang J, Chen $\mathrm{H}$, Deng L, et al. Nerve growth factor improves functional recovery by inhibiting endoplasmic reticulum stress-induced neuronal apoptosis in rats with spinal cord injury. Journal of translational medicine. 2014;12(1):1-15.

73. Zhou F-Q, Zhou J, Dedhar S, Wu Y-H, Snider WD. NGF-induced axon growth is mediated by localized inactivation of GSK-3 $\beta$ and functions of the microtubule plus end binding protein APC. Neuron. 2004;42(6):897-912.

74. Hung K-S, Tsai S-H, Lee T-C, Lin J-W, Chang C-K, Chiu W-T. Gene transfer of insulin-like growth factorI providing neuroprotection after spinal cord injury in rats. Journal of Neurosurgery: Spine. 2007;6(1):35-46.

75. Hong M, Lee VM-Y. Insulin and insulin-like growth factor-1 regulate tau phosphorylation in cultured human neurons. J Biol Chem. 1997;272(31):19547-53.

76. Kanje M, Skottner A, Lundborg G, Sjöberg J. Does insulin-like growth factor I (IGF-1) trigger the cell body reaction in the rat sciatic nerve? Brain research. 1991;563(1-2):285-7. 
77. Wong C, Inman E, Spaethe R, Helgerson S. Fibrin-based biomaterials to deliver human growth factors. Thromb Haemost. 2003;89(03):573-82.

78. Midha R, Munro CA, Dalton PD, Tator $\mathrm{CH}$, Shoichet MS. Growth factor enhancement of peripheral nerve regeneration through a novel synthetic hydrogel tube. Journal of neurosurgery. 2003;99(3):555-65.

79. Sánchez M, Garate A, Delgado D, Padilla S. Platelet-rich plasma, an adjuvant biological therapy to assist peripheral nerve repair. Neural Regeneration Research. 2017;12(1):47.

80. Geoffroy CG, Zheng B. Myelin-associated inhibitors in axonal growth after CNS injury. Curr Opin Neurobiol. 2014;27:31-8.

81. Tang S, Qiu J, Nikulina E, Filbin MT. Soluble myelin-associated glycoprotein released from damaged white matter inhibits axonal regeneration. Mol Cell Neurosci. 2001;18(3):259-69.

82. Lei F, He W, Tian X, Zhou Q, Zheng L, Kang J, et al. GSK-3 inhibitor promotes neuronal cell regeneration and functional recovery in a rat model of spinal cord injury. BioMed research international. 2019;2019.

83. Díaz-Hernandez M, del Puerto A, Díaz-Hernandez JI, Diez-Zaera M, Lucas JJ, Garrido JJ, et al. Inhibition of the ATP-gated P2X7 receptor promotes axonal growth and branching in cultured hippocampal neurons. Journal of cell science. 2008;121(22):3717-28.

84. Cross DA, Culbert AA, Chalmers KA, Facci L, Skaper SD, Reith AD. Selective small-molecule inhibitors of glycogen synthase kinase-3 activity protect primary neurones from death. Journal of neurochemistry. 2001;77(1):94-102.

85. Narayanan SP, Flores Al, Wang F, Macklin WB. Akt signals through the mammalian target of rapamycin pathway to regulate CNS myelination. J Neurosci. 2009;29(21):6860-70.

86. Tyler WA, Gangoli N, Gokina P, Kim HA, Covey M, Levison SW, et al. Activation of the mammalian target of rapamycin (mTOR) is essential for oligodendrocyte differentiation. J Neurosci. 2009;29(19):6367-78.

87. Huang S-P, Chien J-Y, Tsai R-K. Ethambutol induces impaired autophagic flux and apoptosis in the rat retina. Dis Models Mech. 2015;8(8):977-87.

88. Maurer U, Preiss F, Brauns-Schubert P, Schlicher L, Charvet C. GSK-3-at the crossroads of cell death and survival. Journal of cell science. 2014;127(7):1369-78.

\section{Figures}




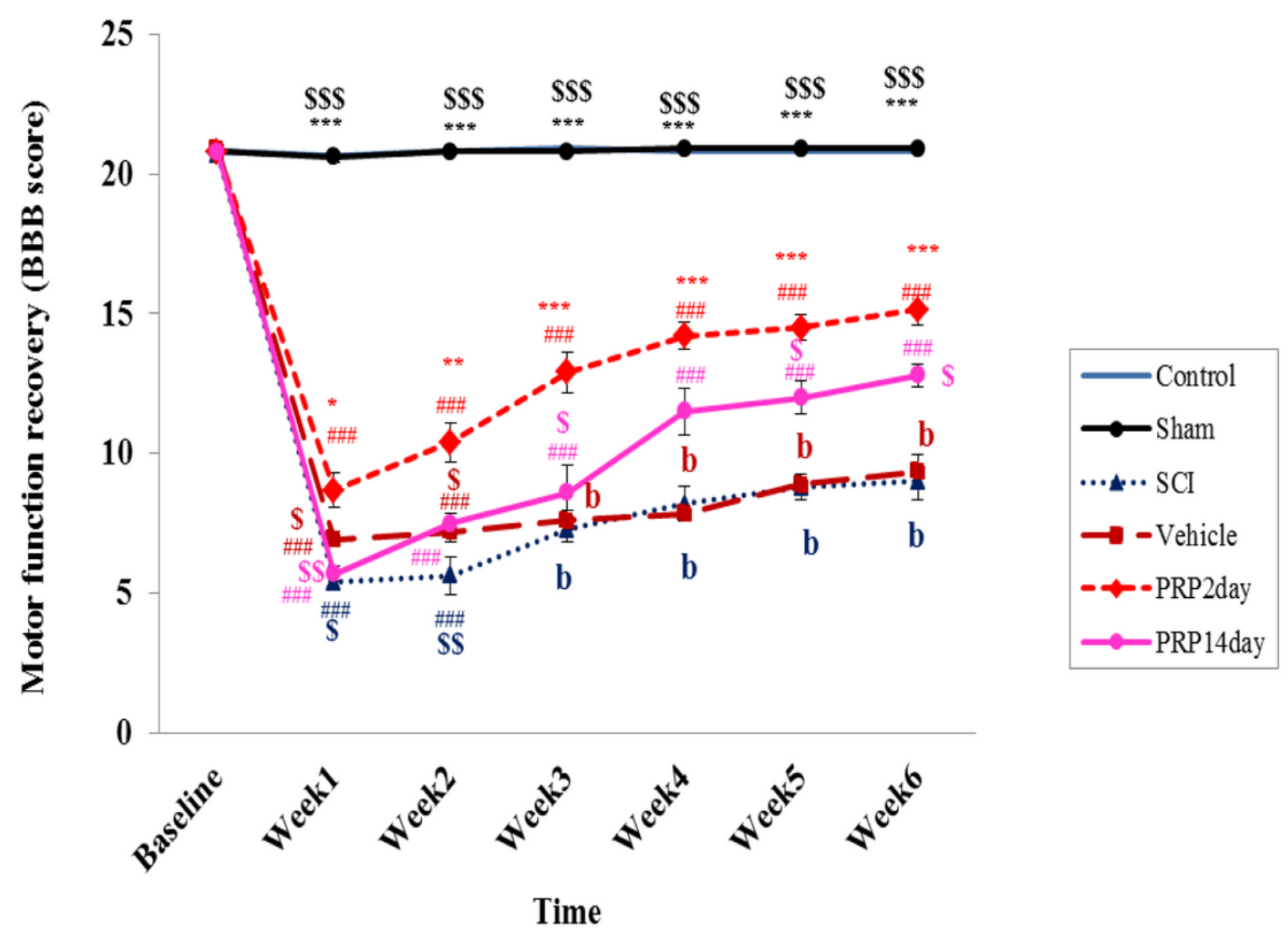

\section{Figure 1}

The effect of intraspinal injection of HUCB- PRP on motor function recovery during six weeks after SCl; quantitative data are expressed as the mean \pm SEM. ${ }^{\star} p<0.05,{ }^{\star \star} p<0.01,{ }^{\star \star \star} p<0.001$ versus SCl groups. \#p $<0.05, \# \# p<0.01, \# \# \# p<0.001$ versus control group., $\$ p<0.05$,

$$
p<0.01
$$

$\$ p<0.001$ versus group which received PRP on the second day after injury. b: \#\#\#, \$\$ 

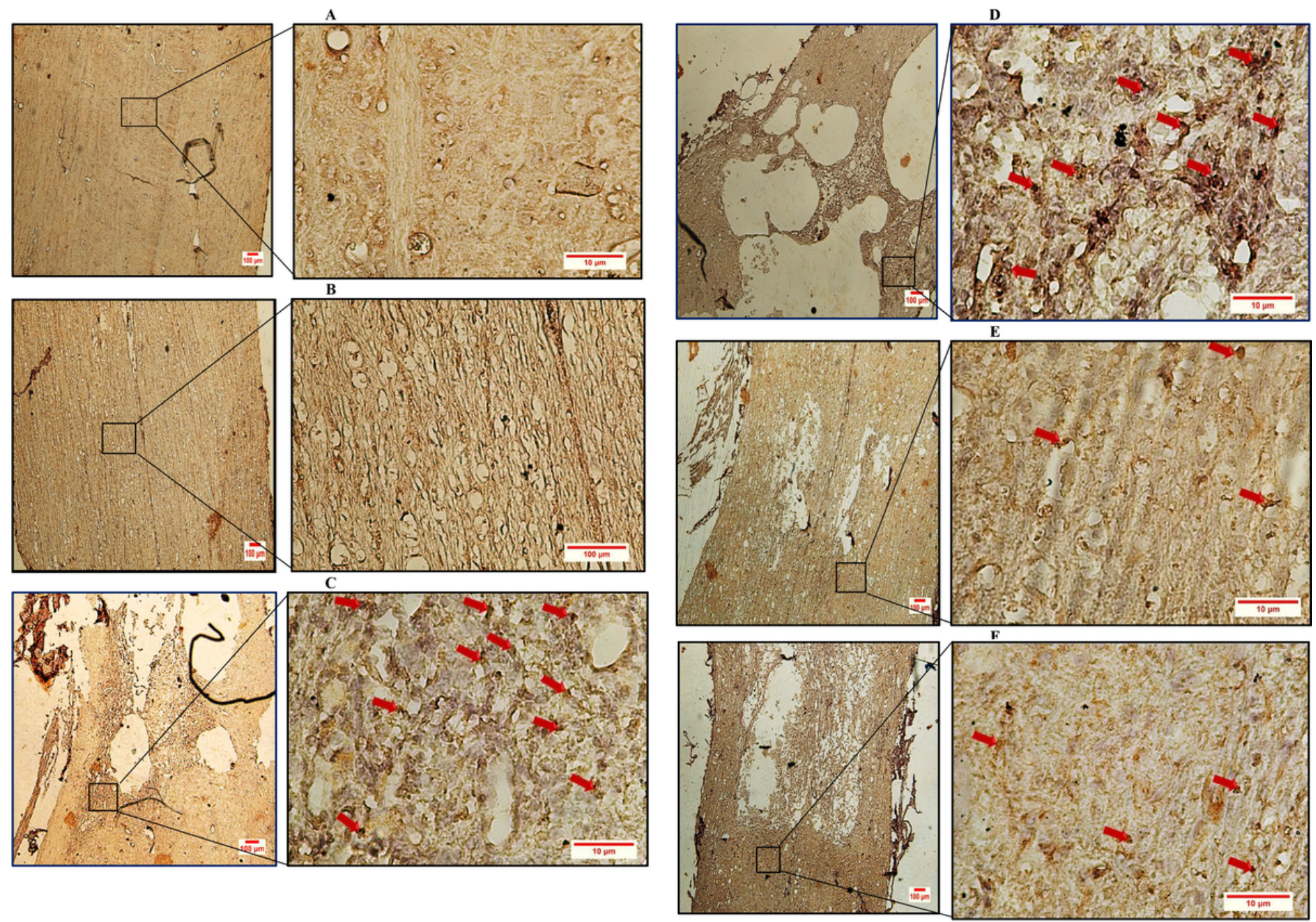

G

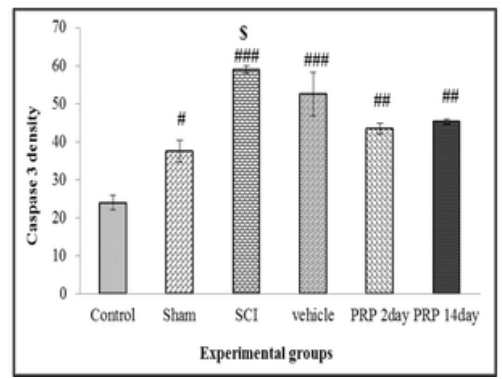

Figure 2

IHC images of longitudinal sections of L2-L3 levels of spinal cord. The IHC images of caspase3 expression in control (A), sham (B), spinal cord injured (C), vehicle (D), PRP 2day (E) and PRP 14day (F) groups were shown. The reduction of caspase 3 as a hallmark of apoptosis by HUCB-PRP is a result of remarkable antiapoptotic activity of HUCB-PRP. Red arrows showed the apoptotic cells. Normalized density of caspase 3 in different experimental groups (G). Data are expressed as mean \pm SEM. \#\#\# $p<0.001, \# \# p<0.01, \# p<0.05$ compared to the control group and $\$ p<0.05$ compared to the groups which received PRP second and fourteen days after $\mathrm{SCl}$. The images on the left showed at an original magnification $\times 4$ and the images on the right at an original magnification $\times 40$. 
A

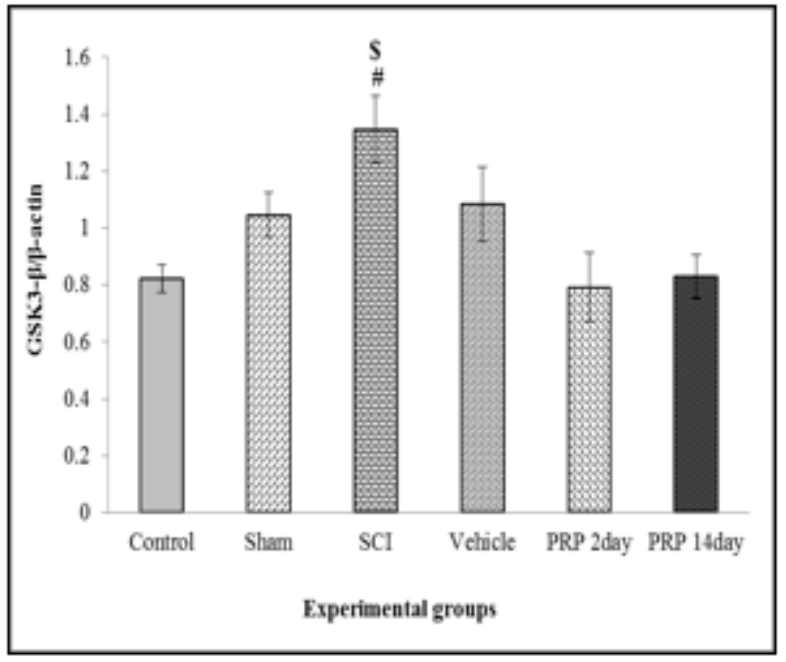

B

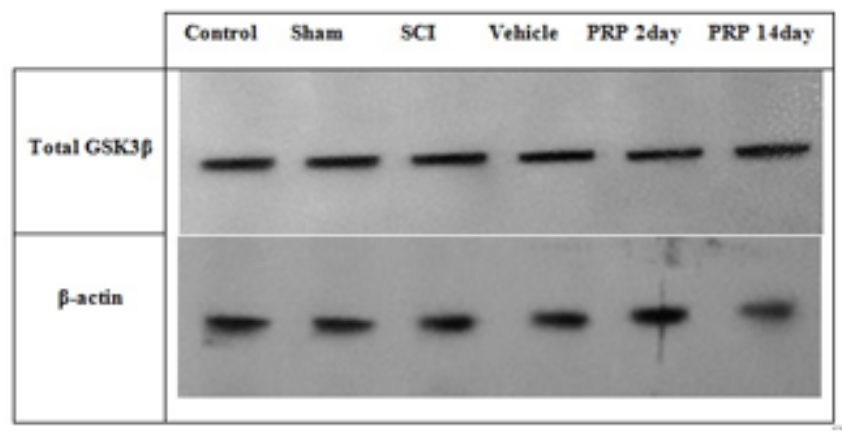

\section{Figure 3}

Western blot analysis of GSK3 $\beta$ protein expression showed that expression of GSK3 $\beta$ in the spinal cord after intraspinal injection of HUCB-PPP in injured rats was decreased. The test was performed thrice on GSK3 $\beta$ proteins and integrated optical density of each band was normalized to corresponding $\beta$-actin as a loading control. Total GSK3 $\beta$ (A); western blot bands of total GSK3 $\beta$ protein (B). Data are expressed as the mean \pm SEM. \# $p<0.05$ compared to the control group and $\$ p<0.05$ compared to the groups which received PRP on the second and fourteenth day after injury.

A

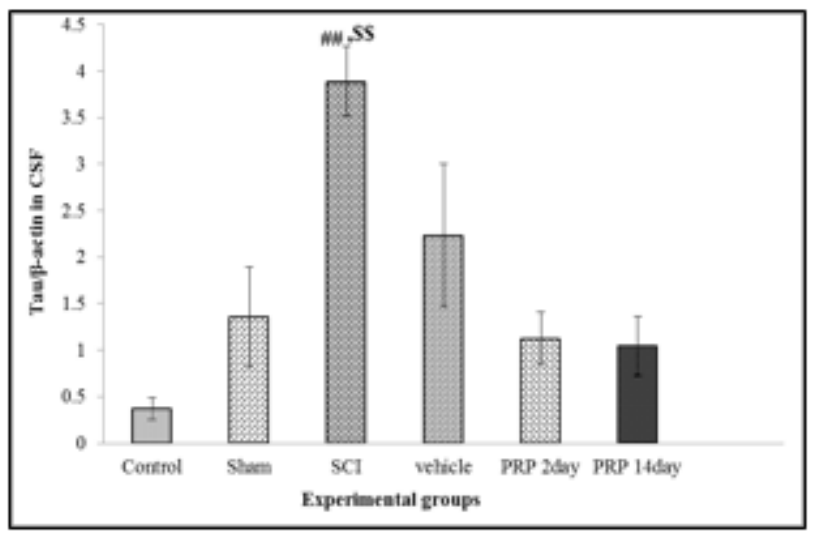

B

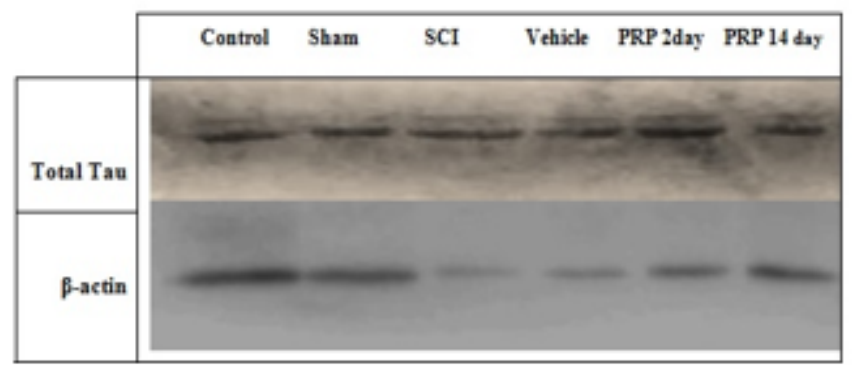

\section{Figure 4}

Western blot analysis of tau protein expression showed that expression of tau in the spinal cord after intraspinal injection of HUCB-PPP in injured rats was decreased. The test was performed thrice on tau proteins and integrated optical density of each band was normalized to corresponding $\beta$-actin as a loading control. Total tau (A); western blot bands of proteins of total tau (B). Data are expressed as the 
mean \pm SEM. \#\# $p<0.01$ compared to the control group and $\$ p<0.01$ compared to the groups which received PRP on the second and fourteenth day after injury.

A

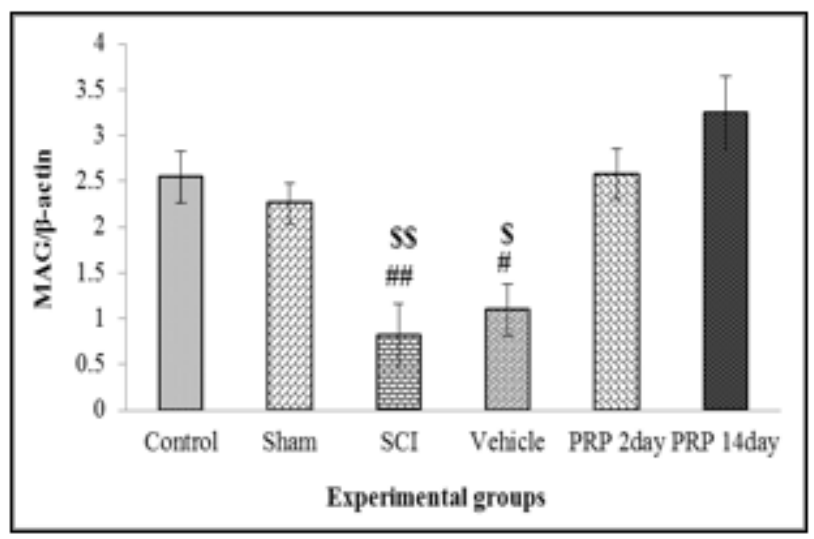

B

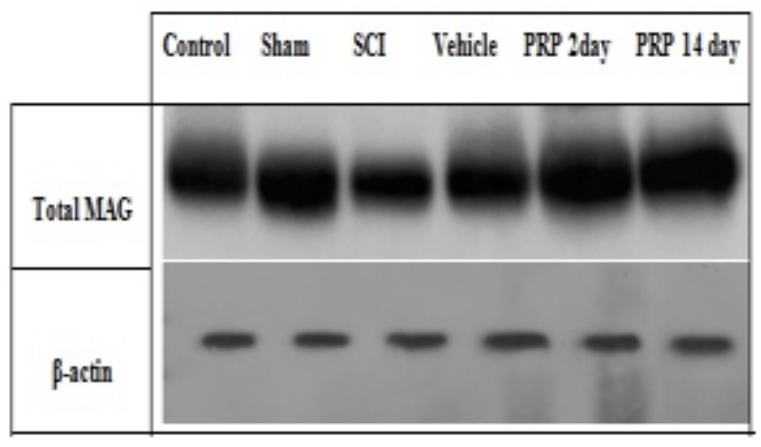

\section{Figure 5}

The increased expression of MAG in the spinal cord after intraspinal injection of HUCB-PPP in injured rats. The test was performed four times on proteins and integrated optical density of each band was normalized to the corresponding $\beta$-actin level. MAG expression (A); western blot bands of proteins (B). Data are expressed as the mean \pm SEM. \#\# $p<0.01$, \# $p<0.05$ compared to the control group and $\$ \$$ $p<0.01, \$ p<0.05$ compared to the groups which received HUCB-PPP on the second and fourteenth day after spinal cord injury. 


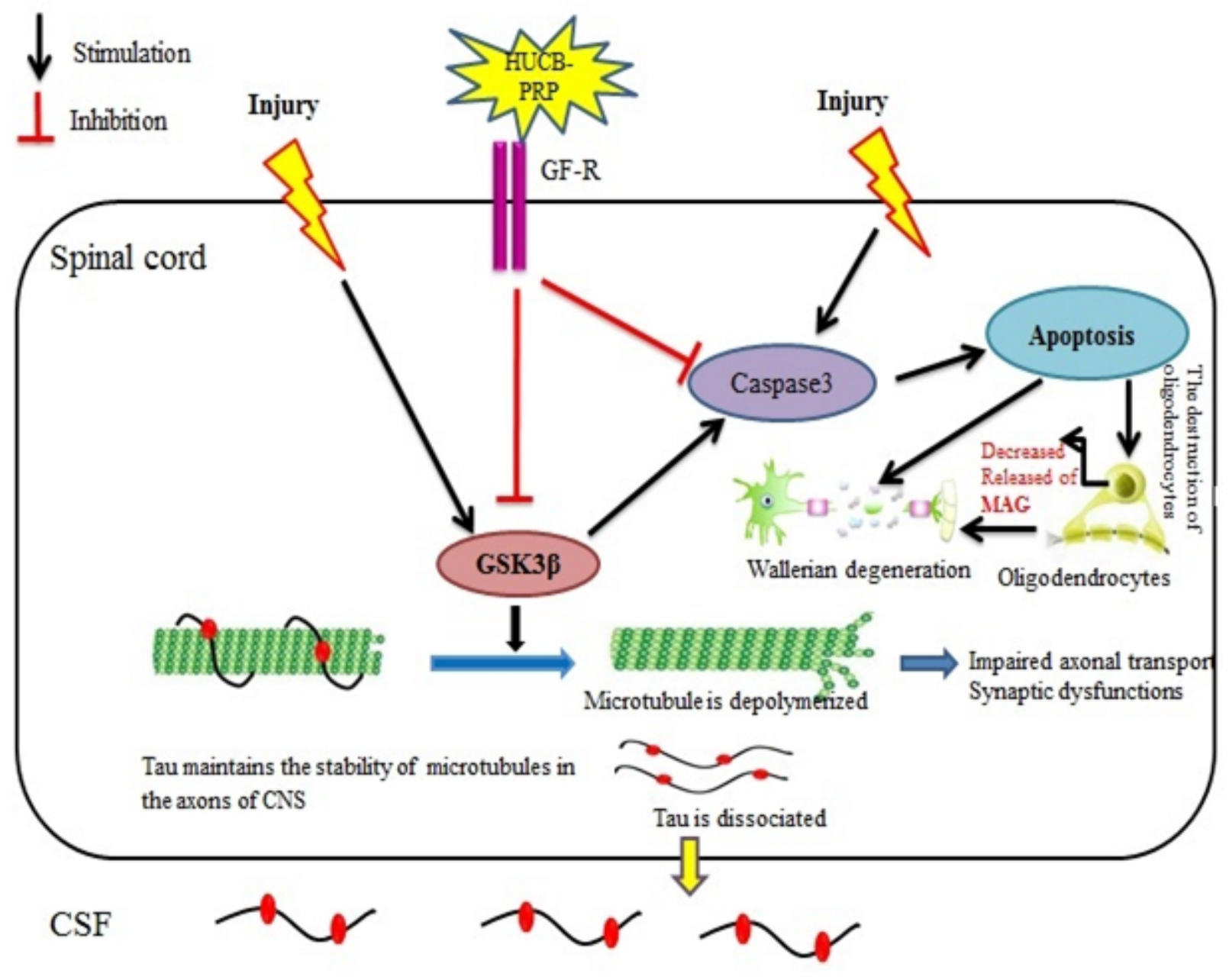

Figure 6

Schematic representation of relation between apoptotic pathways and Gsk3 $\beta$ expression on motor function recovery. The spinal cord injury results in increasing caspase 3 and GSK3 $\beta$. When death signals are received by the cell, the pro-apoptotic protein such as caspase 3 was activated, following this, Wallerian degeneration is enhanced in the cell through the destruction of oligodendrocyte and decrease the expression of MAG. On the other hand, the GSK3 $\beta$ enzyme hyper-phosphorylates tau protein and disconnects it from microtubule. Therefore, impaired connection between tau protein and microtubule, as a result, failed microtubule stability. Also, GSK3 $\beta$ increases caspases 3 . Therefore, GSK3 $\beta$ synergically reinforces the apoptosis process and diminishes the recovery of motor function. HUCB-PRP thereby reversed the above pathway and improve the motor function.

\section{Supplementary Files}

This is a list of supplementary files associated with this preprint. Click to download.

- Graphicalabstract.docx 